\title{
18 From Thomas Mann to Porto Marghera: Material Ecocriticism, Literary Interpretation, and Death in Venice
}

\begin{abstract}
Material ecocriticism' is a methodological approach which, assuming the active expressiveness of matter, extends the category of text to all material formations, taking bodies and landscapes as the bearers of 'material narratives.' Investigating the trope of 'death in Venice,' this chapter proposes a comparative reading of Mann's famous novella, Andrea Zanzotto's lyrical cycle Fu Marghera, and Marco Paolini's theatrical play Parlamento Chimico/Storie di plastica. Its main point, however, is an examination of this theme in the city's own textuality and active materiality. Applying the categories of material ecocriticism, I concentrate on Venice as a text made out of embodied stories - a material text, in which natural dynamics, cultural practices, political visions, and industrial choices are interlaced with human bodies in issues of justice, health, and ecology.
\end{abstract}

Key Terms: Venice, hybridity, storied matter, material ecocriticism, cognitive justice, Thomas Mann, Andrea Zanzotto, Marco Paolini

\section{Ecocriticism, World, Text ${ }^{1}$}

In his Practical Ecocriticism, Glen Love $(2003,16)$ writes: “Teaching and studying literature without reference to the natural conditions of the world and the basic ecological principles that underlie all life seems increasingly shortsighted, incongruous." The world in which we teach and study literature the world in which literature is made is the same world in which humans, along with several millions of other species, live. What physically affects this world, affects all the activities happening in it, including our intellectual and cultural productions. Ecocriticism is an incitement to consider 'culture' not as totally apart from 'nature,' but to see nature and culture, world and text, as mutually permeable. Practically, this can mean many things. For example, it means to examine how literary texts mirror or elaborate on the ecologies of the 'outside world' how they culturally respond to the crises affecting these ecologies. But it can also mean another, interesting thing, namely, that the world itself becomes a text in which these crises along with all the encounters between nature and culture

1 Unless otherwise indicated in the bibliography, English translations in the text are my own. 
are scripted. Thus, ecocriticism is not merely a critical analysis of literary texts, but it asks us to read the world as a text. There is, in other words, a form of eloquence spread in the material forms of this world, in the compound that we call "nature-culture" (cf. Latour 1993, 7; Haraway 2004, 2). This is the standing point of what has been recently codified as "material ecocriticism" (Iovino and Oppermann 2012a; Phillips and Sullivan 2012), a "fourth wave of ecocriticism" (Slovic 2012, 619) that emphasizes the formative and narrative force inbuilt in matter, as well as in "environmental things, places, processes, and experiences" (619). In this view, our world is a storied dimension emerging from the cooperation of nature and culture, of physical elements and discursive practices. The matter of the world, in the form of landscapes, ecosystems, and bodies is here read as a text expressing the interactions of human and nonhuman actors. Ecocriticism becomes therefore an attempt to elicit the implicit message of this text, while also trying to create comparative connections between these material forms and their literary representations: when world and literature combine, as in the case of Venice, the whole expressiveness of reality is enhanced, and we are able to see more.

What do we see in Venice, if we read it as a text? What is its 'material narrative'? Textually interpreted, Venice is an exercise in hybridity. It is so not only because it mixes water and land into a new elemental combination, creating a city out of a hundred little islands suspended in a lagoon, but also because it is an act of hybris, a violation of ontological pacts, literally embodying the Faustian dream of taking land from the waters. It is undeniable that the volatile balance of this combination creates here an incumbent state of danger. Not only is Venice exposed to its amphibious nature and to all the 'natural' consequences of climate change; it is also exposed to decades of polluting practices, due to political and industrial choices, which proved to be 'abstract' from this complex reality. The crisis of Venice is therefore the story of a misinterpretation of its material text. When decisions such as the building of Porto Marghera's petrochemical factory were made, the text 'Venice' was read in isolation from all the rest: in isolation from its ecosystem, its history, its elemental natures. The story of this misinterpretation is narrated by documents and bodies, it is written in cells and legal files, in industrial sludge and algae, in a landscape transformed into highways of pipes, in the air turned into smoke.

Using the paradigm of material ecocriticism, this chapter reads material stories and literary stories through each other, trying to restore the meanings of Venice's storied matter via a comparative reading. After considering the narratives embedded in Venice's body, I take into account three authors: Thomas Mann, Andrea Zanzotto, and Marco Paolini, respectively a novelist, a poet, and an actor-playwright. Scrutinizing how literature interacts and interferes with material textuality, we will see how such interferences add a further dimension to Venice's storied matter, thus helping to accomplish ecocriticism's project of reading into and hence restoring the world's narrative layers. This operation is not intended as a 'local' journey. "Every time I describe a city, I am saying something about Venice,” Marco Polo says in Calvino’s (1997) Invis- 
ible Cities. Venice is "a first city that remains implicit" in all the others (1997, 78). Complementary to this view, we take Venice as a "planetary metaphor" (Bevilacqua 1998), and therefore implicit in our discourse are all the places where the balance between nature and non-nature is precarious, and where this instability becomes an issue of justice and health. In Venice's translucid story, we can catch a glimpse of many other places, near and far, from Bhopal to New Orleans.

\section{Text 1: Venice, Lagoon}

The first textual approach to Venice begins with a plunge into its nature, its remote past. As a matter of fact, we cannot read the text of Venice without looking into its past and "geological unconscious" (Zanzotto 2013, 111), a 'sub-text' made of the evolutionary dynamics of waters, land, climate, ecology, and history. It is in this remote dimension that we find the reasons for Venice's hybridity.

Elementally amphibious, Venice is situated inside a lagoon, a mobile site where the blending of fluvial and saline waters determines unique evolutionary conditions for biomes and ecosystems. Extended over 550 square kilometers, the Venetian Lagoon displays a rich and delicate web of biodiversity, also due to its distinctive microclimate: temperatures are here $2^{\circ} \mathrm{C}$ below the Mediterranean average. This determines a phenomenon called 'Atlanticism,' characterized by the existence of a flora and fauna more similar to the Atlantic than to the rest of the Mediterranean. The Lagoon has a special feature: it breathes with the moon. Tides, whose cycle lasts twelve hours, are the expression of this breath: "It is easy to picture the steady coming-in and going-out of waters as a breath of the lagoon, which 'inhales' high tide and 'exhales' low tide. Like a lung expanding with the incoming air, the lagoon increases its surface with the incoming sea" (Fabbri 2003, 19).

The way the Lagoon looks today is rather recent. Its current hydro-geological conformation dates back to 2500 years ago. We need to travel way back in time to see the Venetian Lagoon originating from the melting of a vast ice gulf, which used to connect Grado with Ancona, the Alps with the central-Italian Apennines. At the end of the last Ice Age (10,000 years ago), the glacier waters started flowing to the Adriatic Sea, forming rivers that carried huge quantities of sediment. In the course of thousands of years, the heaviest sediments fell on the lagoon bed, hardening into very compact solidified clay, called caranto (from the late Latin caris, rock). The remaining sediments accumulated, contributing to the formation of a multitude of small islands. This is Venice's core: a hundred sedimentary islands, covered with a unique vegetation of reeds and other plants, laying on a firm and thick Pleistocene 'palaeo-ground.'

Even though the terra firma was already populated in the Neolithic and the Bronze Age, it was not until the fifth and sixth centuries $\mathrm{AD}$ that the first settlements started appearing on this land-sea. The settlers were mostly fishermen, trying to escape the 
attacks of Visigoths, Huns, and Lombards, nomadic populations coming from the Northern forests of Europe. Looking for shelter, these inland people begun to make their abode on these tiny islands, connecting them with wooden bridges and creating canals. It is in these canals, the poet Andrea Zanzotto $(2013,112)$ writes, that Venice's "metaphysical blood" flows. But these veins required a skeleton, too. The fishermen started stacking wooden piles into the muddy seabed, driving them until they reached the caranto. Underwater, surrounded by salty mud, in an oxygen-free environment, these 25 meter-long oak trunks mineralized. They literally petrified, becoming as hard as concrete - as hard as the caranto itself - thus providing the perfect foundation for the world above. It took an immense quantity of trees to make this "urban forest of buildings" (Zanzotto 2013, 96) and to turn this place into a "beaver-republic" (as Goethe put it in 1786; cf. Goethe 1970, 74). When the primitive palafittes became houses, palaces, streets, a generous part of Europe's forests had joined the caranto in this watery underworld to resurrect in the form of a city: Venice, la Serenissima, for centuries one of the most powerful city-states in Mediterranean Europe and in the world.

What is clear, here, is that this city results from the cooperation of many forces, human and nonhuman. These forces interact in a hybrid compound, forming hybrid, collective stories. Venice is thus a text written by human and nonhuman "makers," to use Jorge Luis Borges's (1985) term. And so Borges pictures this collective making of Venice:

\footnotetext{
Rocks; the rivers whose cradle lies in the mountain peaks; those rivers' waters blending with the waters of the Adriatic sea; the cases and fates of history and geology; riptide; sand; the gradual formation of the islands; the proximity of Greece; fishes; migrating people; the Armorican and Baltic wars; the reed huts; the branches mixed with mud; the inextricable network of canals; primeval wolves; the incursions of Dalmatian pirates; the delicate cotto; terraces; marble; horses; Attila's spears; the fishermen protected by their own poverty; the Lombards; being a site where West and East meet; the days and nights of forgotten generations: these were the makers. (1985, 1332)
}

All these were the makers of the text 'Venice,' a text that had been written and carefully interpreted by generations of citizens and governors. A lagoon is an amphibious ecosystem whose unstable balance is due to the combined action of two concurrent forces: river waters and sea tides. River waters are responsible for carrying sediments to the sea. If this force prevails, the fate of lagoons is to become, in the long run, land. If tides prevail, lagoons become bays or gulfs. For over a thousand years, the Venetian Lagoon - whose main problem was not so much that of being submerged by water, but of being covered by fluvial sediment - was able to keep its peculiar conditions thanks to the wise management strategically carried out by the Republican government. This form of wisdom was a sensible interpretation of Venice's material text: the public authorities and institutions read it as a lagoon, and acted accordingly, thus seconding this 'Faustian dream' before Faust. 'Faustian dream' is here meant 
literally. In his Italian Journey Goethe, though not particularly sympathetic with the population of this 'beaver-republic,' praised the way Venetians controlled their environment, only recommending a few corrections in terms of 'waste management.' So he noticed in the fall of 1786 :

[B]y intelligently improving their system of dredged channels [the Venetians] will do their best to keep their possessions intact.

If only they would keep their city cleaner! It may be forbidden, under severe penalties, to empty garbage into the canals, but that does not prevent a sudden downpour from sweeping into them all the rubbish that has accumulated at the street corners, or, what is worse, from washing it into the drains, which are only meant to carry off waters, and choking them, so that the main squares are in constant danger of being flooded. (Goethe 1970, 98)

In spite of Goethe's recommendations and of the Serenissima's long tradition of water management, the 'sensitive interpretation' of the lagoon's text lasted until 1797, when, by means of the Treaty of Campoformio, Venice and the largest part of its territory were yielded by Napoleon to the Emperor of Austria in compensation for the Netherlands, united to France. Following a bad practice inaugurated by the French conquerors, many portions of the Lagoon were privatized under the Habsburg domination; they were either transformed into agricultural land, or turned into fish farms (Bevilacqua 1998, 129-137). Almost one third of the lagoon was thus subtracted from the free expansion of tides and fluvial waters, and even more damage was inflicted by lowering the level of the canals connecting the city with the lagoon and by enlarging the harbor mouth. Finally, the creation of groundwater wells for industrial use caused the ground level to sink even deeper: the 'economy of land' was devouring the space of the waters (Bevilacqua 1998, 140; De Lucia 2013, 86-90; Salzano 2011).

At the end of the nineteenth century, besides deeper canals, bridges and railways were also built. Other factors, such as the construction of the Porto Marghera industrial plant (here, too, with deep canals to allow huge cargo ships), or the enclosing of sometimes illegal and often unsustainable fisheries, contributed to expose Venice to the force of high tides. The reclaimed areas, once storage spaces for tidewaters, have now become useless: "Less absorption surface, more incoming water, land sinking, sea-level rise, disappearance of natural barriers: these are all little tiles of the puzzle composing Venice's ruin” (Fabbri 2003, 48-49; cf. also Pirazzoli 2011; Somma 2012).

As if they were completely removed from the physical world, some human activities fatally concur with (partly natural) phenomena like subsidence and eustatism, favoring the crumbling of this delicate body. And so the lagoon, from a living place, has turned into scenery. In this 'beautiful setting' thousands of ferries, working and private boats, the enormous cruise ships touching on San Marco Square, cause a supplement of wave power that shatters the palace walls, eroding the wooden piles that constitute the foundations of the city.

Today, in spite of a number of important studies and requests coming from the citizens, the prevailing approach to the protection of Venice's Lagoon continues with 
the practice of textual misinterpretations. Instead of promoting ecologically sustainable measures, the national and local governments have chosen to protect this fragile geo-ecological balance from the water by closing the harbor mouth with a mechanical system of dams. The so-called MOSE project (an acronym for Modulo Sperimentale Elettro-Meccanico, Experimental Electromechanical Module) is not only the latest misreading of the city's material textuality, but also one of the biggest financial businesses in Italy. Not only, in fact, is the MOSE a "monstrous solution" (De Lucia $2013,90)$ draining all the money allocated for the protection of the Lagoon, strongly impacting the landscape, but it is already proving insufficient for its purpose.

\section{Text 2: Venice, Industry}

Thomas Mann's Lido, that on which Aschenbach dies in the early 1900s, had already become extinct at the end of the 1960s, chased away by the reclamation works necessary to make room for industry. In the Land Use Plan of 1962 (still valid in 1990), this destination (or induced destiny) was expressed with threatening recklessness: "The industrial area of Porto Marghera will chiefly contain those plants emitting smoke, dust or health-impairing fumes in the atmosphere, releasing polluting substances into the water, and producing vibrations and noises" (qtd. in Fabbri 2003, 66). Again, the abstraction of this 'narrative of development' from the material text of Venice is patent. And it is also patently uncanny, if one considers the magnitude of this artificial satellite, launched into Venice’s orbit: “18 kilometers of navigable canals (waterways), 33 kilometers of docks, and over 2000 hectares of industrialized peninsulas that, like metastases, [spread] into water" (2003, 37-38).

A rigorous description of Porto Marghera could match Calvino's Invisible Cities; with a substantial difference, though: the Petrolchimico is indeed very visible, and smellable, too:

\footnotetext{
A true city, entirely surrounded by high walls, not far from Marghera's residential area, with miles and miles of inner roads and little streets, bordering on the lagoon. From here, in the distance, you [can] see Venice and its belfries. But if you [turn] around, you [see] the endless pipes, thin and huge, new and old, rusty and repaired, whole or covered with creative patches [creatively mended], at the ground level as well as 15 meters high or more, endlessly long, straight or crooked. They [enter] in mysterious hangars and barracks, whence they [get] out, to chase other hangars and barracks in a senseless, unfathomable labyrinth. [Everything is] merged in pungent and acrid smells, sometimes sweetish, sometimes intolerable, among fumes and gas spills of any color and extension. (Casson 2007, 34-35)
}

More than a satellite, industrial Venice materializes here as "a planet fallen into sea" (Marchiori 2003, 127), an anti-Venice. Indeed, the above-ground face of Marghera is the macabre, grotesque, and surreal pendant of Venice's watery underworld. In this industrial surrealism, the elemental hybridity of this city is forced to merge with other 
elements, unknown, unexpected, frightening, and unforgiving. The human is here only a disposable wedge in the cannibal mechanism of the 'development narrative.'

But this 'futurist' chapter was inaugurated well before the time of artificial satellites and space exploration. Exactly one year before Thomas Mann's visit to Venice (and four before the beginning of WWI), the theorist of Futurism, Filippo Tommaso Marinetti, cast a spell Against Passéist Venice (Contro Venezia passatista). It was 27 April 1910:

We repudiate the old Venice, enfeebled and undone by centuries of worldly pleasure [...].

We repudiate the Venice of foreigners, a market for counterfeiting antiquarians, a magnet of snobbery and universal imbecility, a bed whose bottom has been staved in by caravans of lovers, the bejeweled hip-bath of cosmopolitan courtesans, the cloaca maxima of passéism.

We want to cure and heal this putrefying city, this magnificent sore from the past. We want to reanimate and ennoble the Venetian people, fallen from their ancient grandeur [...].

We want to prepare the birth of an industrial and military Venice that can dominate the Adriatic Sea, that great Italian lake.

Let us hasten to fill in its little reeking canals with the ruins from its leprous and crumbling palaces.

Let us burn the gondolas, rocking chairs for cretins, and raise to the heavens the imposing geometry of metal bridges and factories plumed with smoke, to abolish the cascading curves of the old architecture.

Let the reign of divine Electric Light finally come to liberate Venice from its venal moonlight for furnished rooms to let. (Marinetti et al. 2009, 67-68)

"Let the reign of divine Electric Light finally come," Marinetti said. And divine Electric Light came into Venice by way of Giuseppe Volpi, first Count of Misurata. Volpi, who would later become Mussolini's Minister of Finance, was the owner of SADE, at that time the major Italian corporation for the production of electric energy. Volpi had promoted the creation of an "industrial Venice" to be placed in an area of the lagoon which had to be reclaimed and filled with ground. Its construction started in 1917. The land, which was state-owned, was conceded to the industrial group completely free of charge. In 1919, the first industrial plants had been completed, and in 1920-1921 Marghera was already host to metallurgic factories and units for the production of sulfuric acid. Around 1923 "the productive plants [were] already twenty-seven, [...] all powered with the energy furnished by the SADE corporation [...]. In 1929, the factories [were] fifty-five, out of which fifteen produce[d] chemicals; the workers [were] around ten thousand" (Fabbri 2003, 26). A considerable urban expansion started to surround the industrial area. In 1932, there were 5000 residents (today there are about 28000).

The history of Marghera is also the story of a dense concentration of industrial and financial interests, binding together the main industrial corporations in Italy and beyond: SAVA furnished aluminum alloys, ILVA the iron and steel products, whereas Montecatini provided the chemical agents necessary to transform mineral and petroliferous products. All these corporations are part of the not always glorious epopee of Italian industrial capitalism. But Marghera's history is also a story of war: Marghera, 
in fact, was a production site for yperite or sulphur mustards, the infamous 'mustard gas' used by the Italian army in Ethiopia and Libya (1936), in spite of the Geneva Protocol of 1925. Predictably, the Venetian industrial site also became a 'sensitive target' during WWII.

In the 1950s the era of petrochemical production began. The former corporations operating in Marghera merged in a new company named "Edison," which became "Montedison" after merging with Monsanto and Union Carbide (the owner of Bhopal's Union Carbide). In 1951, on a new expanse of land (called Industrial Zone II), the production of chlorine and PVC started: Italy entered the plastic era. Certainly, in these wealthy years of 'well-mannered' tycoons and enlightened working classes, ecological or 'merely aesthetic' concerns were not part of any political agenda.

As a symbol at once ironic and gruesome of the material textuality of this place, we can consider the way Industrial Zone II was constructed. While the first industrial site was built on clean ground, the foundations of Industrial Zone II were assembled using the chemical and metallurgical sludge of the 'early days': "To put it bluntly, it was an industrial site laying on a humongous toxic dump, quantifiable in ten million tons" (Fabbri 2003, 41). Textually interpreted, this site is a material mise en abyme of the whole pollution system, almost a metaphysical self-representation of toxicity.

Obviously, the whole existence of the Petrolchimico comes at an astounding cost for the human and natural ecology of the lagoon. Incredible amounts of toxic waste are produced over the decades, in spite of the denunciations of people, workers, environmental associations, and notwithstanding systems of rules meant to protect public health. Marghera is therefore also a story of irresponsibility, deceit, and stubborn denial. It is a story of how the pursuit of industrial interests (or economic interests in general) became so 'absolute' (that is, so abstract) as to falsify the texts of reality in form of territory, peoples' rights and health, an age-old landscape and the lagoon's ecological balance. In order to accumulate profit, this absolute industrial narrative became literally world-less. As a matter of fact, ever since its foundation, the Marghera petrochemical factory had produced the most dangerous agents (including dioxin and phosgene), systematically keeping the workers uniformed about their noxiousness, occulting and manipulating scientific reports, which were already available from the 1950s and 1960s. In 1973, the World Health Organization officially declared the carcinogenicity of vinyl chloride monomer (VCM), whose most frequently induced pathologies include cirrhosis, hepatopathologies, brain, lung, and liver cancer. But the production in the Petrolchimico continued.

In the 1980s, Marghera finally became an environmental case due to its systematic practice of dumping in the lagoon toxic pollutants such as sludge from the production of aluminum, zinc, sulfuric and fluorhydric acid. As the historian Piero Bevilacqua $(1998,147)$ notes, the lagoon "has now turned into a private landfill for [these] factories.” In 1984, it was documented that every day and for at least two decades some 4000 tons of phosphogypsum had been poured into the sea. This reckless practice ceased (at least officially) only in 1988, but for some years that sludge continued 
to be processed and used as the basis for construction and road-making materials. After that date, many of those pollutants were illegally dumped in Africa, or sank in the Mediterranean Sea on board of the so-called 'ships of poison': secretly wretched ships clandestinely loaded with tons of all sorts of hazardous pollutants (cf. $\rtimes 19$ Mediterranean Ecocriticism).

In his long and important memoir titled La fabbrica dei veleni (The Poison Factory, 2007), the magistrate Felice Casson has demonstrated how, in the decades of its industrial flourishing, the chief executive officers of Porto Marghera did their best to bury all the medical and scientific evidence related to the actual toxicity of the chemicals produced in the factory. The studies conducted by Italian and international researchers were deliberately ignored or boycotted, in a game of trans-Atlantic industrial complicities aimed at the singular goal of continuing a dangerous production, regardless of the cost for the workers' health. Casson's $(2007,31)$ investigations evinced a 'secrecy protocol' binding the world's major petrochemical corporations: “A criminal and generalized 'pact of silence,' agreed upon between 1972 and 1973 by all the leaders of the world's [petrochemical] industries. This agreement was promoted by European corporations, with Montedison in the front row." The result of the epidemiological research, when authorized, should remain top secret. The risk of contamination for workers and residents was generally undermined, if not completely denied (cf. also Bettin and Dianese 2003; Rabitti 1998). Among all the layers of justice (social, ecological, historical) of which residents and workers were deprived, the most important was the cognitive one.

But the voice of the cells was telling another story, and this story became gradually evident and understandable by the affected subject. To speak of the voice of the cells, here, is not simply a metaphor (cf. $\lambda 1$ The Lightest Burden). As biosemiotician Wendy Wheeler $(2006,12)$ notes, our social life, our work, the hierarchies we are placed in, are "written in our bodies in terms of flourishing or [...] illness." In terms of our biology, the coupling of environment and body "is a form of conversation, [...] a kind of narrative of conversational developments" $(2006,126)$. In this conversation, the human body, in its immune, nervous, and endocrine systems, elaborates and keeps the memory of "the many 'not-me' which it encounters" (122). This memory is elaborated by our cells, and shows itself in pathological forms. To Marghera's workers, the cells' voice was telling a story of inner mutation, of trans-substantiation between plastic and flesh. As Nancy Tuana explains:

Beginning at a molecular level, we know that phtalates and vinyl chloride affect [...] a complex interaction that can result in cancer. Workers inhale PVC dust, and those who live by incinerators inhale it as plastics are burned. The viscous porosity of our bodies and that of PVC allow for an exchange of molecules, where PVC and phtalates pass through the porosity of skin and flesh [...]. Plastic becomes flesh. (2008, 200-201)

Tuana's words describe a situation taking place in New Orleans in the aftermath of Katrina. In this respect, there are strong similarities between Venice and New Orleans. 
Like the undeniable evidence of cancer cases and pollution lays bare the hidden story of Marghera's factory, Katrina, too, exposes the plots of reality told by these material texts: the body cells, the bodies of the people suffering from exploitation and lack of protection. In Marghera, like in New Orleans, these bodily stories were ironically denied for many years. Rather than stopping the production, the workers were forced to operate wearing anti-gas masks; it was recommended that they use special toothpaste, or drink milk.

Finally, mostly thanks to the collective efforts of the workers, a trial was ordered in 1998. Thirty-one executives were indicted. The accusations were mass murder, environmental disaster, mass culpable homicide, missing workplace safety, water and food poisoning, and the construction of illegal waste dumps. In a shocking decision, however, in 2001 all the defendants were acquitted. In 2004, though, the Appeal Court reversed the verdict, sentencing five executives to serve one and a half years in jail for culpable homicide. The supreme level of justice finally confirmed this sentence. What can be said today is that the Marghera petrochemical factory is responsible for killing one hundred fifty-seven workers (this figure is necessarily increasing), and it has caused the almost irremediable ecological degradation of Venice's Lagoon.

The "putrefying city," whose "leprous and crumbling" matter Marinetti (2009) wished to "reanimate" by means of "metal bridges and factories plumed with smoke" in 1910 was dying of cancer less than a century later. And this cancer was caused by those very factories, by those very smokes. This was, after all, the Italian industrial dream. But this dream was, unfortunately, 'absolute': it was completely disconnected from the textual evidence of reality. Marghera (and the Margheras of the world) are the price paid for this dream of an 'absolute industrial narrative.' The only way left to "cure and heal" this new "magnificent sore" is to restore the material textuality of Venice's body.

\section{Text 3: Venice, Literature}

In May 1911, Thomas Mann finally touches Venice's body. He will give this experience a literary elaboration almost immediately thereafter, publishing Der Tod in Venedig the following year. Much has been said about this work. Prominent scholars and skilled critics have seen this masterpiece of modernist literature as a manifesto of decadence, scrutinized the inner conflict of art and life, or analyzed the queer aesthetics of Aschenbach's voyeuristic relationship to the young Tatzio. Also particularly intense have been the explorations of the autobiographical background of the novel, in search of the inspiration sources behind the protagonist's figure (cf. Schede 2006; Shookman 2003; Lenhert and Wessel 2004). In the context of our reading, however, there are two main points to which I would like to draw attention: first, the fact that Mann's novella is a story about bodies, whose macro-category is Venice's body itself 
as a hybrid and collective organism; secondly, the fact that Death in Venice is also the story of how discursive falsifications of Venice's bodily texts generate forms of cognitive injustice, culminating in death.

Venice's body is Aschenbach's body: an aging, decaying, unquiet, "embellished" body - a dirty, sweating, sublimely dying artist's body. But Venice’s body is also Tatzio’s body an unspeakably beautiful young body. In this beautiful body, the germ of decay resides for the very fact that this is a living body, a biologically determined matter. The only possibility for this body to stay beautiful would be to have its form frozen in time, to die. It might be for this very reason that the artist Aschenbach secretly enjoys the idea of Tatzio being ill and not destined to a long life, of his teeth revealing poor health (Mann 2004, 62): this early death would thus preserve his exquisite form from corruption. But Venice's body is all of this city's bodies, its dirty streets and white Istria stones, its seabirds and sandbanks, its brackish waters, its people - rich and poor, powerful and powerless. They are all caught in the tangle of space-time-matter on which biology depends. Here, Mann's decadent aesthetics inhibit any romanticization of Venice's landscape. In his iconographic imagination, rather than Canaletto we sense Guercino, Et in Arcadia Ego. In fact, Venice is not a landscape here. It is not a picturesque setting, a mere background, but it is itself a character of Mann's novella. It is a corporeal presence one can smell, feel, touch. Venice possesses here its own pervasive metabolic agency. This uncanny agency becomes fatal when another actor enters into the mix: cholera. In this heavily breathing atmosphere, Venice and all its bodies share the same fate.

Nevertheless, this fate is not due to a combination of merely material circumstances: "the city was diseased and was concealing it out of cupidity" (Mann 2004,104). Indeed, Death in Venice is the story of a sanitary emergency, and of the fraudulent way the city's authorities handle this emergency. The cholera outbreak is caused by a number of coalescing agencies: environmental conditions, the climate, poor hygiene, "the prevailing insecurity" of the populace (122). Fatal, however, is the way "corruption in high places," undermining or covering the danger, mingles with all these agencies, thereby amplifying the explosion of the epidemic (122). We have here a clear example of how material elements coupled with discursive practices result in a series of "often unpredictable and unwanted actions" (Alaimo 2010, 2), whose effects are fractally disseminated throughout the bodies of reality. In the porosity of Venice's bodies, matter and discourse interact, producing uncontrollable effects. The mediators of such interaction are here the sirocco and the lagoon's "feverous vapors" (Mann 2004, 64), body cells and police, a basket of strawberries, and the complicity between negligent authorities and the people in Venice. What is striking, however, is the way information is deliberately manipulated and the truth artfully disguised. But finally, everything comes into sight in a clear and comprehensive picture: 
The Venetian authorities issued a statement to the effect that health conditions had never been better, then took the most essential precautions against the disease. But some food must have been contaminated [...] because, denied or concealed as it was, death ate a path through the narrow streets, and the premature summer heat [...] was particularly conducive to its spread. [...] [F]ear of the overall damage that would be done, concern over the recently opened art exhibition in the Public Gardens and the tremendous losses with which the hotels, the shops, the entire, multifaceted tourist trade would be threatened in case of panic and loss of confidence - proved stronger in the city than the love of truth and respect for international covenants: it made the authorities stick stubbornly to their policy of secrecy and denial. The chief medical officer of Venice, a man of outstanding merit, had [...] been quietly replaced by a more pliable individual. The populace knew all this, and corruption in high places together with the prevailing insecurity and the state of emergency [...] led to a certain degeneracy. (Mann 2004, 122)

In the face of the materiality of danger, a falsifying narrative provides reassuring discourses, so as to disable the alarm without neutralizing the bomb. The echoes between this story and that of the petrochemical factory are hard to overlook. In saying this, however, I am not alluding to a bizarre mimicry between art and life. What I mean is that literature, combined with the material texts of reality, provides theory to better understand these texts. If we read literature and reality through each other, we might better recognize recurring patterns: in our case, a game of unheeded material eloquence and pursued discursive deception. In this game, cognitive justice people's right to know and to choose accordingly is completely nullified. Both in Mann's Venice and in Porto Marghera, the combination of physical danger, political complicity, and textual falsification of reality are fatal. As Belle-époque travelers become disposable resources for an economic system feeding on tourists, so Porto Marghera's workers and residents taste the violence of an abstract, world-less, and indifferent industrial narrative. The only difference between the two situations emerges if we consider Aschenbach's death. Aschenbach is aware of the epidemic and willfully decides to die, whereas Porto Marghera's people undergo a much more subtle coercion, accentuated by the economic blackmail that the factory exercises on the community.

But, by providing a theory to better see reality, literature can also provide categories to interpret reality. In so doing, literature transforms reality itself into its own narrative. This is what two Italian authors, Andrea Zanzotto and Marco Paolini, respectively do. Zanzotto does it by offering a poetic reading of Venice's invisible natures and wounded body. Paolini does it by socializing these wounds and turning them into a performative memory that can be shared, cognized, and re-enacted (cf. $\pi 29$ Literary Place and Cultural Memory).

Andrea Zanzotto (1921-2011) is without any doubt one of the most important contemporary European poets (cf. Barron 2007). Among the numerous compositions he devotes to Venice, particularly interesting for our purpose are five poems composing a cycle titled "Fu Marghera (?)" (“The Late Marghera (?)," published in 2009) and a work of narrative prose, "Venezia, forse” ("Perhaps, Venice,” 1976). I concentrate here on the latter. 
In "Venezia, forse" Zanzotto is not afraid of Venice's ambiguous textuality. His prose strips the city of its picturesque aura, and gives it back to its weird life - a strange, quasi-zombie life, in which destructive and vivifying forces co-exist along with the discordant fates of the city's storied body. After an intensely lyrical opening, hesitating between geological vastness and a delicate coming-near, Zanzotto focuses on Venice's inner fluctuations and ambivalences. These fluctuations, he suggests, require first of all a different way of thinking Venice: "every thought referring to it has to be located elsewhere" (Zanzotto 2013, 88), it has to "shatter any confirmed perspective" (87). In other words, to entirely meet Venice, we need to uproot ourselves from it, "entering so deep inside as to 'pierce' [it], arriving elsewhere, and seeing [this place] anew" (Giancotti 2013, 13). "Perhaps" one can approach Venice only from this elsewhere, Zanzotto suggests, or "perhaps" we can possess it only as a simulacrum, a picture in a painting, a postcard replica, or a fragment of the huge touristic imagination. But, comprehended from the distance of this elsewhere, Venice appears as a whole, a round universe, in which the idealized pictures make way for the material complexity of a 'monstrous' ecology (cf. Cohen 2014). We are here in a "world of crossings" (Zanzotto 2013, 96), a "precarious/eternal” dimension (88) where the Adriatic sea shows "its nature of poor pool now thickened with sludge, where the purest mother-of-pearl blends with the shady rainbows of industrial dejections" (89), where "[p]us and petroleum, phosgene and worms [...], incompetence and vain ambition, are [...] facts" (108). As Zanzotto says:

\footnotetext{
Humans and things find themselves together in asking for help against the neighboring furnaces for chlorine and phosgene, against the black magic that fertilizes all earth with death. Quite different from the traditional myth of the "death in Venice" is the death looming from Marghera and from the whole womb of the dry land, whose horizons are worm-eaten by the encastellations and towers of "industry." $(2013,103)$
}

To accept Venice's double nature means to go past its metanarratives - whether of 'absolute beauty' or 'industrial progress.' Beauty, Zanzotto says (consonant with Mann) is not absolute; it has not loosen its tie with the materiality of its object; hence, it implies decay, corruption, and death: every living matter is, sub specie aeternitatis, a corpse. 'Industrial progress,' on the other side, is an abstraction - and it is an abstraction as it abstracts its substantive processes of withdrawal, transformation, consumption, and pollution from the world. Its very reality, though, depends on the world and therefore it is, like beauty, non-absolute, but ultimately embedded in its materiality. In that it mesmerizes governments, decision makers, and workers, 'industrial progress' is as fatally deceitful as black magic. But death is also a chance of solidarity for getting together humans and nonhumans, because "the haunting of monsters reveals communal values, shared aspirations and lived ethics [...] as well as the coinhabitance and alien thriving of the nonhuman" (Cohen 2014, 273). This shocking coinhabitance implies thus ethical and cognitive disclosures: 
The most distressingly strident couple in the world, Venice fastened together with Mestre-Marghera (which one is the living, which one is the corpse?), all of a sudden challenges you to a salvaging suture through the obscenity of the real and of the present; it challenges you [...] to 'move further,' [...] toward a never-seen where even evil could be stopped, emptied of its power, and rehabilitated as a sign, a trace, a form. (Zanzotto 2013, 104-105)

Like living body and corpse, the mother-of-pearl blended with industrial dejections, matter and anti-matter, Venice and Marghera - this anti-Venice - are one and the same. To see Venice means to see this living monstrosity. As an alternative, we should concur with Giorgio Agamben $(2011,11)$ and admit that Venice is no longer a corpse, but rather a specter - a "blabbering" presence "left to drain on the fondamente, together with rotten algae and plastic bottles." But, if we really want "to move further," we have to transform mourning into cognition, and develop new ways of seeing that stop the evil, as Zanzotto demands. And this is just what a material-ecocritical interpretation of all the 'implicit Venices' aims at: stopping the evil and rehabilitating it as a sign. To see Venice (which is the same as to see the world) is to embrace all these contradictions and to recognize them as parts of this place's bodily text. It means to recognize the world as a site of unremitting interferences, hybridizations, encounters. In this 'moving-further,' even beyond the Aristotelian principle of non-contradiction ("which one is the living, which one is the corpse?"), is the key to understanding the many wounds of this huge body of which we are part.

Even more than novels and poetic prose, theater can contribute to socializing these wounds. One of the most original and engagé Italian playwrights, Marco Paolini (born in Belluno in 1956) is the author of a number of plays which enact what he calls teatro civico, 'a civic theater': long monologues about events of the recent past, often, but not exclusively, from an Italian standpoint (his most celebrated works are about two socio-environmental catastrophes, both displaying an underground connection to Venice: the collapse of the SADE-owned Vajont dam in Friuli and the Union Carbide's factory disaster in Bhopal, India). Through these acts of 'narrative resistance,' a collective civil memory is reconstructed as a necessary operation of cognitive justice. Venice is 'implicit' in many of his plays, but it emerges as the subject of two of them: Il Milione: Quaderno veneziano (The Million: A Venetian Notebook, 1997) and Parlamento chimico: Storie di plastica (Chemical Parliament: Plastic Stories, 2001). This latter play is about Porto Marghera.

Parlamento chimico is based on a significant amount of data, including historical documents, the workers' medical records, the proceedings of the trial against the heads of the petrochemical factory, scientific and technological descriptions of the production processes, and many personal stories of people living inside or near the factory. Here again, the 'narrative agencies' are material. As Paolini (qtd. in Marchiori $2003,79)$ says in an interview: "productive processes and plants play the leading role; finance, chlorine: they have now become my characters." The factory itself emerges as a body. Paolini portrays this body as a naked body, so naked that one can almost 
picture it through X-rays: "you see the whole skeleton and all the nerves, the circulatory system and the inner organs of the factory: cracking towers, refinery plants, autoclaves, pipes” (qtd. in Marchiori 2003, 38). Looking into this organic nudity creates a new porn, an industrial porn:

Naked factories that, when the lights are turned on, let you glimpse their circulatory system, their organs... this is porn. Therefore men like it. I know of many people seduced at night by the petrochemical factories spread in the landscape: this is something that lures mostly males, with all those fires, lights, structures... (Paolini 2002, n. p.)

This obscenity is the same that Zanzotto saw in the ambivalent corpse/body of Venice: the present, for Paolini like for Zanzotto (and like for Pier Paolo Pasolini before them), is obscene. Still more so, if one considers the circularity between such obscenity and the discursive obscenity of the Italian industrial metanarrative. All this is obscene not because it reveals too much, but because it hides what should be shown.

Paolini connects facts and framework into a narrative 'civic' memory and thus creates a game of mirroring and resonances within the naked and wounded bodies of reality, clearly enacting literature's function of being a 'cultural ecology' of a society (cf. $\lambda 7$ Cultural Ecology of Literature). And so Marghera becomes all the Margheras of the world, near and far: it is Bhopal; but it is also the archetype figure of the global theaters of war, from WWI and WWII to more recent wars: "Marghera plants can help us picture the VCM factory bombed in Belgrade, and the euphorizing sweetish-tasting cloud, which goes unnoticed, covered by smoke and the exploding bombs" (Marchiori 2003,39 ). Performed in front of an audience of workers (which are themselves textual matter on which this story is written), of informed citizens and of common people, the play echoes reality indefinitely, and in so doing, it produces multiple reverberations of meanings. (It is worth noting that the preparatory representation of Parlamento chimico took place in 2001 in Castiglioncello, Tuscany, near the Solvay petrochemical plant of Piombino, an 'associate' of Montedison: the Marghera factory's story was thus set within another similarly storied factory.) Paolini's play connects all these people with all these places, putting together all the pieces of this puzzle. Literature is here helping reality to perform itself and its interconnectedness via the story, the stage, and the audience. This is a practice of civil resistance and narrative liberation.

Put on stage in Venice in 2003, during the Carnival, and right after the second sentence of the Marghera trial, Parlamento chimico is the story of a political failure in front of the textuality of matter. In an interview, Paolini commented: “The language of politics do not include the admission of failure. Its narrative 'art' is conventionally structured as to always tell things in terms of defense, consolidation. But who shall tell failures, if no politician will care to do it?” (qtd. in Marchiori 2003, 155). Venice's bodies do. But literature does it, too. It does it by transforming evils into signs, thus liberating the voices of reality. 


\section{Text 4: World}

The way we, not only as ecocritics, but as intellectuals in general, relate to the material eloquence of the world, is crucial to our work. This approach involves, in fact, a reflection on the ethical role of the humanities in creating tools apt to understand the tangles of material agencies, socio-ecological sustainability, and human responsibilities. To read the world as a text and to implement correct interpretations of this textuality is not only ecologically correct, but also a necessary condition for creating social forms of cognitive justice, and hence practices of social liberation and environmental responsiveness.

The importance of this approach is evident. Whenever the 'text' of the world is misread, uncontrollable consequences ensue. This misreading happens all the times we believe that the boundaries between 'the outside' and 'the inside' are firm and solid; it happens when we think of the 'world outside' as inert matter and we imagine it as unrelated to the 'world inside' (cf. Alaimo 2010). It happens all the times we set up an alienated relationship to reality. Whenever this occurs, as Barbara Kingsolver wrote, we fall into

a mass hallucinatory fantasy in which the megatons of waste we dump in our rivers and bays are not poisoning the water, the hydrocarbons we pump into the air are not changing the climate, overfishing is not depleting our oceans, fossil fuel will never run out, wars that kill masses of civilians are an appropriate way to keep our hands on what's left, we are not desperately overdrawn at the environmental bank, and, really, the kids are all right. (Kingsolver 2003, 13)

An alienated relationship to (and, therefore, misinterpretation of) reality is also the one that, for example in Italy, leads ecomafia clans to intersperse densely populated areas with toxic waste, areas where their own families and they themselves live. In their criminal hallucination, they act as if they do not have to breathe the same air, drink the same water, eat the same food produced in that land, or live in houses built on polluted ground.

A city always hovering above itself, Venice, too, has fallen prey to an alienated narrative. It is often an abstract narrative, hard to reconcile with the reality of things. The aim of this chapter was exactly this: to use literary and material texts in order to 'restore' Venice's story, trying to do justice to this complex reality. In this, my idea of material ecocriticism is consonant with the premises of Hubert Zapf's (2010, 138; cf. $\lambda 7$ Cultural Ecology of Literature) theory of literature as cultural ecology: combined with the evidence of Venice's material textuality, literary works play, in my view, too, a decisive role in highlighting socio-historical injustices, at the same time contributing to processes of "cultural self-renewal, in which the neglected biophilic energies can find a symbolic space of expression and of (re-)integration into the larger ecology of cultural discourses." In both Zapf's vision and mine, literature is instrumental for reality to emerge as a whole picture, in a way that discloses the enclosed parts and sheds light on the unspoken bonds hidden in this whole. 
Barry Commoner's $(1971,39)$ first law of ecology reads: "Everything is connected to everything else. There is one ecosphere for all living organisms and what affects one, affects all." However empirically hard to prove, this "law" is helpful for understanding our discourse. If we think that most of the plastic composing the infamous Great Pacific Plastic Patch consists of PVC and related substances, essentially deriving from petroleum; if we think how these eerie bodily presences are interacting with the sea's biodiversity, oceanic streams, the atmosphere, climate, and (via the food chain) our own life; and if we consider that this oceanic plastic was produced in industrial plants like Marghera (or like Bhopal, or New Orleans), using the same procedures, creating the same pollution, generating the same diseases, exploiting and cognitively defrauding people in the same way, and participating in the same deceitful industrial 'narratives' - whereas "corruption in high places" (Mann 2004, 122) means death in lower ones, whether human or not - then we will admit that Commoner might be on the right track, and that there is an actual connection between the tiles of this mosaic. Like the cholera and death in Venice, the climate change that threatens to erase a lagoon in Northern Italy is also due to interplaying factors, which include 'natural' agents as well as human discourses, sometimes disconnected from the matter of the world.

A material ecocritical approach is the way we, as literary critics who believe in the existence of reality, try to see all these apparently disconnected elements as parts of a wide story, and to make sense of this story. This is, to use Zapf's words, our way to re-integrate these elements in the 'larger ecology' of reality. As our moral duty, we have to responsibly discard falsifying narratives and heed the eloquence of things, using literary imagination as a privileged tool to penetrate this eloquence. Maybe not arbitrarily, we put all these elements - both material and cultural - into a comprehensive frame, one that acts like Kant's regulatory ideas: it provides directions, inviting us to act $a s$ if these apparently disjointed tiles would compose a picture, a chapter in a complex text we call 'the world.' Such an as if is our strongest weapon in the struggle for cognitive justice. If we really hope that "the evil is blocked, emptied of its power, and rehabilitated as a sign," that is the means we have.

\section{Bibliography}

\subsection{Works Cited}

Agamben, Giorgio. Dell'utilità e degli inconvenienti del vivere tra spettri. Venice: Corte del Fontego, 2011.

Alaimo, Stacy. Bodily Natures: Science, Environment, and the Material Self. Bloomington: Indiana University Press, 2010. 
Barron, Patrick. "Introduction." The Selected Poetry and Prose of Andrea Zanzotto: A Bilingual Edition. Trans. and ed. Patrick Barron. Chicago and London: University of Chicago Press, 2007. $1-14$.

Bettin, Gianfranco, and Maurizio Dianese. Petrolkiller. Milan: Feltrinelli, 2003.

Bevilacqua, Piero. Venezia e le acque: Una metafora planetaria. Rome: Donzelli, 1998.

Borges, Jorge Luis. "Venecia." Tutte le opere. Vol. 2. Ed. Domenico Porzio. Milan: Mondadori, 1985. 1332-1335.

Calvino, Italo. Invisible Cities. Trans. William Weaver. New York: Vintage Books, 1997.

Casson, Felice. La fabbrica dei veleni: Storie e segreti di Porto Marghera. Milan: Sperling \& Kupfer, 2007.

Cohen, Jeffrey Jerome. “Grey.” Prismatic Ecology: Ecotheory Beyond Green. Ed. Jeffrey Jerome Cohen. Minneapolis: Minnesota University Press, 2014. 270-289.

Cohen, Jeffrey J., and Lowell Duckert, eds. Elemental Ecocriticism: Thinking with Earth, Air, Water, and Fire. Minneapolis: Minnesota University Press, 2015.

Commoner, Barry. The Closing Circle: Nature, Man, and Technology. New York: Knopf, 1971.

De Lucia, Vezio. Nella città dolente: Mezzo secolo di scempi, condoni e signori del cemento dalla sconfitta di Costantino Sullo a Silvio Berlusconi. Florence: Castelvecchi, 2013.

Fabbri, Fabrizio. Porto Marghera e la Laguna di Venezia: Vita, Morte, e Miracoli. Milan: Jaca Book, 2003.

Giancotti, Matteo. “Radici, eradicazioni: Introduzione.” Luoghi e paesaggi. By Andrea Zanzotto. Milan: Bompiani, 2013. 5-25.

Goethe, Johann Wolfgang. Italian Journey. Trans. W. H. Auden. London: Penguin Books, 1970.

Haraway, Donna. The Haraway Reader. New York: Routledge, 2004.

Iovino, Serenella, and Serpil Oppermann. "Theorizing Material Ecocriticism: A Diptych.” ISLE 19.3 (2012): 448-475.

Kingsolver, Barbara. “A Good Farmer.” The Nation 277.14 (2003): 11-18.

Latour, Bruno. We Have Never Been Modern. Trans. Catherine Porter. Cambridge, MA: Harvard University Press, 1993.

Lenhert Herbert, and Eva Wessel, eds. A Companion to the Works of Thomas Mann. Rochester, NY: Camden House, 2004.

Love, Glen A. Practical Ecocriticism: Literature, Biology, and the Environment. Charlottesville: Virginia University Press, 2003.

Mann, Thomas. Death in Venice. 1912. Trans. Michael Henry Heim. New York: HarperCollins, 2004. Marchiori, Fernando. Mappa Mondo: Il teatro di Marco Paolini. Turin: Einaudi, 2003.

Marinetti, Filippo Tommaso, et al. “Against Passéist Venice.” Futurism: An Anthology. Eds. Lawrence Rainey, Christine Poggi, and Laura Wittman. New Haven and London: Yale University Press, 2009. 67-70.

Paolini, Marco. "Parlamento chimico: Storie di plastica Frammenti di testo." Jolefilm. http://www. jolefilm.com/produzioni/teatro/parlamento-chimico/. 2002 (3 June 2014).

Phillips, Dana, and Heather I. Sullivan. "Material Ecocriticism: Dirt, Waste, Bodies, Food, and Other Matter." Material Ecocriticism. Eds. Heather Sullivan and Dana Phillips. Special issue of ISLE 19.3 (2012): 445-447.

Pirazzoli, Paolo. La misura dell'acqua. Venice: Corte del Fontego, 2011.

Rabitti, Paolo. Cronache della chimica: Marghera e le altre. Naples: Cuen, 1998.

Salzano, Edoardo. La Laguna di Venezia. Venice: Corte del Fontego, 2011.

Schede, Hans-Georg. Thomas Mann, Der Tod in Venedig. Stuttgart: Reclam, 2006.

Shookman, Ellis. Thomas Mann's "Death in Venice": A Novella and Its Critics. Rochester, NY: Camden House, 2003.

Slovic, Scott. “Editor’s Note.” ISLE 19.4 (2012): 619-621. 
Somma, Paola. Imbonimenti: Laguna, terra di conquista. Venice: Corte del Fontego, 2012.

Tuana, Nancy. "Viscous Porosity: Witnessing Katrina." Material Feminisms. Eds. Stacy Alaimo and Susan Hekman. Bloomington: Indiana University Press, 2008. 188-213.

Wheeler, Wendy. The Whole Creature: Complexity, Biosemiotics, and the Evolution of Culture.

London: Lawrence \& Wishart, 2006.

Zanzotto, Andrea. Luoghi e paesaggi. Ed. Matteo Giancotti. Milan: Bompiani, 2013.

Zapf, Hubert. “Ecocriticism, Cultural Ecology, and Literary Studies.”Ecozon@ 1.1 (2010): 136-147.

\subsection{Further Reading}

Barad, Karen. Meeting the Universe Halfway: Quantum Physics and the Entanglement of Matter and Meaning. Durham: Duke University Press, 2007.

Bennett, Jane. Vibrant Matter: A Political Ecology of Things. Durham: Duke University Press, 2010.

Cohen, Jeffrey J., and Lowell Duckert, eds. Ecomaterialism. Special issue of Postmedieval: A Journal of Medieval Cultural Studies 4.1 (2013).

Cohen, Jeffrey J., and Lowell Duckert, eds. Elemental Ecocriticism: Thinking with Earth, Air, Water, and Fire. Minneapolis: Minnesota University Press, 2015.

Iovino, Serenella. "Steps to a Material Ecocriticism: The Recent Literature about the 'New Materialisms' and Its Implications for Ecocritical Theory.” Ecozon@ 3.1 (2012): 134-145.

Iovino, Serenella. “Material Ecocriticism: Matter, Text, and Posthuman Ethics.” Literature, Ecology, Ethics: Recent Trends in European Ecocriticism. Eds. Timo Müller and Michael Sauter. Heidelberg: Winter Verlag, 2012. 51-68.

Iovino Serenella, and Serpil Oppermann, eds. Material Ecocriticism. Bloomington: Indiana University Press, 2014.

Phillips, Dana, and Heather Sullivan, eds. Material Ecocriticism. Special issue of ISLE 19.3 (2012). 